\title{
Articles
}

\section{The Public and Private Sides of Harmonized Standards: James Elliott Construction v. Irish Asphalt}

\author{
By Pierluigi Cuccuru*
}

\begin{abstract}
In James Elliott v. Irish Asphalt, the Court of Justice of the Union addresses the interplay between the EU legal order and harmonized standards-i.e. non-binding technical specifications for products drafted by private bodies upon request of the Commission. The judgment offers interesting insights from the public law and the private law points of view. This Article touches upon both aspects. First, it considers that the Court extends its jurisdiction over harmonized standards under Article 267 TFEU, thus paving the way for a deeper intersection between European judiciary and technical standardization. Second, the paper highlights the Court's understanding of the interplay between harmonized standards and national private law. In this latter regard, it is argued that a rigid separation between technical standards and legal provisions might be excessively formalistic considering the use of technical standards in practice.
\end{abstract}

\footnotetext{
*Ph.D Candidate in Law, Sant'Anna School of Advanced Studies. Contact: p.cuccuru@santannapisa.it
} 


\section{A. Introduction}

With the James Elliott v. Irish Asphalt judgment ${ }^{1}$ the Court of Justice of the European Union ${ }^{2}$ affirmed its jurisdiction over harmonized standards under Article 267 TFEU. Harmonized standards (HSs) are non-binding technical specifications for goods and services drafted by private associations-the European Standardization Organizations (ESOs)-upon formal request of the Commission and referenced in the Official Journal of the European UnionOJEU.

The case gave the Court the opportunity-for the first time-to shed light on the legal nature of HSs as well as to clarify their positioning within the EU acquis. Moreover, the decision touched upon the relationships between European technical standards and national contract law. This Article intends to sketch both aspects. As a premise, section B will outline the essential features of European technical standardization, thus setting the framework that the discussion falls within. Section $\mathrm{C}$ will then introduce the facts that triggered the case, as well as the questions referred to the Court. The main arguments and findings of the judgment will be then presented and commented upon, isolating public law insights-in section D-from private law issues-in section E. With regard to the former, the new intersection between European judiciary and technical standardization will be investigated. With regard to the latter, the actual links between technical standards and private law will be highlighted. Some concluding remarks will follow in section $\mathrm{F}$.

\section{B. Essentials of the New Approach to Technical Harmonization and Standards}

The mutual recognition principle alone cannot prevent national differences in product requirements from arising. ${ }^{3}$ First, Member States-MSs - may still derogate to the freedom of movement of goods on general interest grounds, thus fragmenting the market. ${ }^{4}$ Second, the National Standardization Bodies-NSBs-of the MSs may issue non-binding private standards for domestic application that naturally fall outside the scope of free movement

\footnotetext{
${ }^{1}$ Case C-613/14, James Elliott Constructiong Ltd. v. Irish Asphalt Ltd., 2016 E.C.R. I-821.

${ }^{2}$ Hereinafter, "the Court."

${ }^{3}$ According to the mutual recognition principle, national authorities shall refrain from imposing additional requirements on goods lawfully produced and/or marketed in another Member State. The principle was first sketched in Case C-120/78, Rewe-Zentral AG v. Bundesmonopolverwaltung für Branntwein, 1979 E.C.R. I-42, para. 8 (Cassis de Dijon) and further developed in subsequent case law. See, Case C-525/14, Comm'n v. Czech Republic, 2016 E.C.R. I-714, para. 35; Case C-481/12, UAB “Juvelta" v. Vl “Lietuvos prabavimo rūmai," 2014 E.C.R. I-11, para. 17.

${ }^{4}$ Express derogations to free movement of goods are established by the Consolidated Version of the Treaty on the Functioning of the European Union art. 36, May 9, 2008, 2008 O.J. (C 115) 47 [hereinafter TFEU]. Moreover, the "mandatory requirements" doctrine developed by the Court since Cassis de Dijon allows Member States to depart from free movement provisions where overriding reasons of general interests are alleged.
} 
law. Initially, the approximation of product requirements was pursued through detailed product-by-product legislation-the so-called "Old Approach" to harmonization. Soon enough, this technique turned to be highly ineffective and inefficient. ${ }^{5}$ A new regulatory design for harmonizing product requirements was therefore proposed. Backed up by the notification systems of technical regulations and standards established by Directive 83/189/EEC - the Information Directive-the Council triggered the "New Approach to Technical Harmonization and Standards" in 1985. ${ }^{6}$ The New Approach consists of a publicprivate cooperation, by which the European legislature shall limit itself to identify the essential requirements for product manufacturing and marketing, whereas recognized private associations - the European Standardization Organizations (ESOs) - shall develop pan-European technical standards of voluntary application for implementing those same requirements. The three recognized ESOs - the CEN, ${ }^{7}$ the $\mathrm{CENELEC}^{8}$, and the $\mathrm{ETSI}^{9}$ - gather the delegates of the NSBs and carry out standard-setting tasks either upon the Commission's request or of their own motion-in response to industry needs. In both instances, technical standards are issued at the end of a consensus-inspired process, through which a myriad of technical committees and working groups aim at balancing national positions and the different economic and societal interests at stake. ${ }^{10}$ Once approved, the standards are translated into the official languages of the EU and are made available at domestic level by the NSBs, which hold copyright on them. Standards drafted upon a request issued by the Commission are eventually referenced in the OJEU as "harmonized standards" - HSs. The publication of a reference to standards in the OJEU has substantive legal effects: Conformity with HSs grounds a presumption of conformity with legislative requirements that MSs are bound to respect, and which accordingly allows compliant goods to be freely traded within the Internal Market. ${ }^{11}$ The regulatory framework of the European standardization system

\footnotetext{
${ }^{5}$ See Jacques Pelkmans, The New Approach to Technical Harmonization and Standardization, 25(3) J. OF COMMON MKT. STUD. 249, 251 (1987).

${ }^{6}$ Council Resolution 136/01, of 7 May 1985, on a New Approach to Technical Harmonization and Standards 1985 O.J. (C 136) 1.

${ }^{7}$ Comité Européen de Normalisation.

${ }^{8}$ Comité Européen de Normalisation Électrotechnique.

${ }^{9}$ European Telecommunications Standards Institute.

${ }^{10}$ In general, standardization activities follow the "Code of Good Practice" established by the Annex III to the 1995 WTO Agreement: Technical Barriers to Trade (Jan. 1, 1995) [hereinafter TBT Agreement]. The Code is specified by the Jan. 21, 2000 TBT Committee's “Decision on Principles for the Development of International Standards, Guides and Recommendations with Relation to Articles 2, 5 and Annex 3 of the TBT Agreement."

${ }^{11}$ See Council Resolution 136/01, supra note 6, at Annex II, para. VII (The presumption of conformity might be in any case challenged by MSs whenever the safety of individuals, domestic animals, or the integrity of property is at stake).
} 
has been recently amended and systematized by Regulation (EU) 1025/2012, ${ }^{12}$ which adds to the 2008 New Legislative Framework for the marketing of products. ${ }^{13}$

\section{James Elliott v. Irish Asphalt: Facts and Referred Questions}

In December 2014, the Supreme Court of Ireland asked the Court of Justice to give a preliminary ruling on a widely used HS in the construction industry. The facts are easily explained: The parties in the dispute-James Elliott Construction Ltd. and Irish Asphalt Ltd.entered a supply contract in 2004, by which the former agreed to provide the latter a construction aggregate with characteristics established by an Irish standard implementing HS "EN:13242:2002" drafted by CEN. James Elliott Ltd. used the aggregate for building a youth facility in Dublin. Soon after its completion, cracks appeared in the structure, which rendered it unusable. James Elliott ascribed the damages to an excess of pyrite in the aggregate supplied, and on this basis sought compensation from Irish Asphalt. The High Court of Ireland held Irish Asphalt liable for the infringement of Article 14(2) of the Sale of Goods Act, as amended by the 1980 Sale of Goods and Supply of Services Act. This provision establishes a merchantability clause which, if not expressly excluded by the parties, requires that the goods purchased are of merchantable quality and fit for their purpose. Irish Asphalt appealed the decision before the Supreme Court of Ireland, which in turn refers for a preliminary ruling under Article 267 TFEU.

The Irish tribunal essentially asked, (1) whether a European $\mathrm{HS}^{14}$ implemented by a national standard referred in a private contract is subjected to the Court's interpretation under Article 267 TFEU; (2) in case of an affirmative answer, whether compliance to-and breach of -the HS at issue shall be exclusively proven through the means specified by the standard itself, and only at the time of production or supply of the good(s); (3) whether "merchantability," "fitness for purpose," or similar quality-related clauses established by national law are to be considered "technical regulations" for the purposes of the Information

\footnotetext{
12 Regulation (EU) 1025/2012 of the European Parliament and of the Council of Oct. 252012 on European Standardisation, Amending Council Directives 89/686/EEC and 93/15/EEC and Directives 94/9/EC, 94/25/EC, 95/16/EC, 97/23/EC, 98/34/EC, 2004/22/EC, 2007/23/EC, 2009/23/EC and 2009/105/EC of the European Parliament and of the Council and Repealing Council Decision 87/95/EEC and Decision No 1673/2006/EC of the European Parliament and of the Council, 2012 O.J. (L 316/12).

${ }^{13}$ The "New Legislative Framework" of 9 July 2008 consists of Regulation (EC) 765/2008 of July 9, 2008, Setting Out the Requirements for Accreditation and Market Surveillance Relating to the Marketing of Products, 2008 O.J. (L 218/30), Decision 768/2008/EC of July 9, 2008, on a Common Framework for the Marketing of Products, 2008 O.J. (L 218/82), and Regulation (EC) 764/2008 of July 9, 2008, Laying Down Procedures Relating to the Application of Certain National Technical Rules to Products Lawfully Marketed in Another Member State, 2008 O.J. (L 218/21).

${ }^{14}$ In this specific case, standard EN 13242:2002 implementing Directive 89/106 EEC of Dec. 21, 1998, on the Approximation of Law, Regulations and Administrative Provisions of the Member States Relating to Construction Products, 1998 O.J. (L 40) 12.
} 
Directive ${ }^{15}$ and should be accordingly disapplied if not properly notified to the Commission; (4) whether products manufactured in accordance with HSs should for this reason alone be presumed to fulfil a merchantability or fitness for purpose clause established by national law, and whether such presumption can be rebutted just with the means provided by the standard, and at the moment of the supply of the goods only; (5) in case of an affirmative answer to the previous question-i.e. should a HS standard and the merchantability clause overlap - the Irish court also asks whether the limit for sulphur content established by the standard shall be considered as an essential element for the presumption of merchantability established by the directive on construction products to arise; and finally (6) whether proof of CE marking is a necessary condition for benefiting from the presumption of conformity. Evidently, the judgment draws upon both the public law and the private law sides of the European standardisation system, which will be briefly considered in this order.

\section{The Public Side of Harmonized Standards: Toward a Judicialization of the New Approach?}

The positioning of HSs alongside EU public-private law divide has so far remained unclear. The ambiguity directly depends on the peculiar mix of private and public features which characterizes technical standards prepared under the New Approach. On the one hand, HSs are private and non-binding documents issued by private non-profit associations and protected by copyright. On the other hand, HSs are requested by the Commission, drafted taking into account the essential requirements laid down by the corresponding harmonization legislation, and enacted in accordance with the procedural rules established by Regulation (EU) 1025/2012. Also, HSs have substantive legal effects under EU law once referenced in the OJEU. Building upon these elements, in James Elliott the Court tried to shed some light on the significance of HSs within the Union's legal order, as well as on the role that European judges can play in European standardisation.

\section{The Jurisdiction of the Court of Justice over HSS}

In his opinion to the case, Advocate General Campos Sánchez-Bordona argued that HSs arein substance-acts of the Union, and as such, subjected to judicial interpretation under Article 267 TFEU. ${ }^{16}$ On the contrary, the Court adopted a more cautious approach: While it did eventually consider HSs as part of EU law ${ }^{17}$-and accordingly affirmed its jurisdictionat the same time the Court implicitly acknowledged that these measures are not "acts of the

\footnotetext{
${ }^{15}$ At the time the facts occurred, Directive 98/34/EC of June 22, 1998, Laying Down a Procedure for the Provision of Information in the Field of Technical Standards and Regulations, 1998 O.J. (L 204/37) (EC), repealing Directive $83 / 189 /$ EEC.

${ }^{16}$ Case C-613/14, supra note 1, at para. 40 (Opinion of Advocate General Campos Sánchez-Bordona).

$17 / d$.
} 
institutions, bodies, offices or agencies of the Union." ${ }^{18}$ In sum, the Court included HSs into the EU legal order while keeping the ESOs at the edge of the Union's institutional layout. Despite that telling difference, the Court and the Advocate General grounded their reasoning on the same arguments.

First, HSs are technical documents that directly implement Union's legislation. As such, they shall fall within the scope of Article 267 TFEU even though materially drafted by private bodies. That conclusion preserves the uniform application of EU law across Member Statesi.e. the very raison d'être of the preliminary ruling mechanism. Should the Court be impeded from interpreting measures implementing Union's legislation, the scope of Article 267 TFEU would be put in jeopardy. ${ }^{19}$ The Court further specified this argument by referring to the Sevince ${ }^{20}$ and Deutsche Shel ${ }^{21}$ judgments. Both decisions concerned measures issued by quasi-regulatory bodies established by international agreements signed by the Community. ${ }^{22}$ Although these bodies were not embedded into the institutional architecture of the Community, ${ }^{23}$ on those occasions the Court broadened the-at the time particularly narrow-boundaries of Article $177 \mathrm{EEC}^{24}$ and eventually affirmed its jurisdiction over the acts issued by those same bodies. Similarly, by embracing technical standards issued by private entities-but substantially linked to the EU legal order-the Court attempted to preserve the uniformity of law. ${ }^{25}$

${ }^{18} / d$. at para. 34 (“[...]the Court has jurisdiction to interpret acts which, while indeed adopted by bodies which cannot be described as 'institutions, bodies, offices or agencies of the Union', are by their nature measures implementing or applying an act of EU law").

${ }^{19} / d$.

${ }^{20}$ Case C-192/89, S. Z. Sevince v. Staatssecretaris van Justitie, 1990 E.C.R. I-3461.

${ }^{21}$ Case C-188/91, Deutsche Shell v. Hauptzollamt Hamburg-Harburg, 1993 E.C.R. I-363.

${ }^{22}$ Specifically, Sevince called into question the "Agreement establishing an Association between the European Economic Community and Turkey" signed in Ankara on 12 September 1963, concluded on behalf of the Community by Council Decision 64/732/EEC of Dec. 23, 1963, on the Conclusion of the Agreement Establishing Association Between the European Economic Community and Turkey; Deutsche Shell, on the contrary, concerned the "Convention on a Common Transit Procedure" concluded on May 20, 1987 between the Republic of Austria, the Republic of Finland, the Republic of Iceland, the Kingdom of Norway, the Kingdom of Sweden, the Swiss Confederation, and the European Economic Community, approved on behalf of the Community by Council Decision 87/415/EEC of 15 June 1987.

${ }^{23}$ The organs established by the international agreements at stake had indeed a mixed composition of EC and nonEC delegates. See Council Decision 64/732/EEC supra note 22, at art. 23(1).

${ }^{24}$ EEC Treaty art. 177(1)(b) (only admitted preliminary rulings on "the validity and interpretation of acts of the institutions of the Community and of the ECB").

${ }^{25}$ Case C-613/14, supra note 1, at paras. 44-45 (Opinion of Advocate General Campos Sánchez-Bordona. AG Campos adds that a purely formalistic interpretation of TFEU art. 267 would inevitably compromise the harmonization efforts carried out by the Union: Because the Court has jurisdiction to rule on any act related to full harmonization 
Second, the Court recalled the legal effects that follow the publication of HSs in the OJEU. Reference in the OJEU provides products compliant with HSs with a presumption of conformity with legislative requirements. This presumption is binding on Member States, and consequently opens the doors of the Internal Market to any product manufactured and/or marketed in accordance to the specifications established by HSs. Arguably, the presumption of conformity attached to HSs somehow implies a positive endorsement by European institutions. In this sense, HSs enter the Union's legal order as "part of EU law." 26

Third, the Court underlined the strong links between ESOs' standard-setting activities and the Commission within the framework of the New Approach. A harmonized standard is indeed ". . . strictly governed by the essential requirements defined by [a] directive, initiated, managed and monitored by the Commission, and its legal effects are subject to prior publication by the Commission of its references." ${ }^{27}$ The development of HSs is moreover subjected to public procedural rules, which constrain the discretion of the ESOs and eventually steer the entire standard-setting mechanism. In light of this, the Court is further persuaded to consider HSs as an integral part of EU law, and accordingly affirms its jurisdiction over them under Article 267 TFEU.

\section{Re-shaping Judicial Role within the New Approach}

The James Elliott decision caused quite a stir in the standardization community. ${ }^{28}$ Yet, its concrete consequences are not easy to estimate. Surely enough, the judgment has cross-cutting constitutional implications, that Advocate General Campos and commentators have not failed to pinpoint. Among the most relevant issues, the legitimacy of ESOs' activities

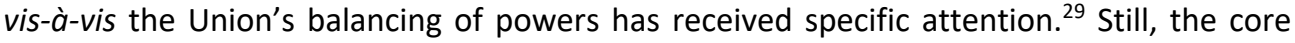

\footnotetext{
legislation, that should be also true for any measure issued within the New Approach framework. If this were not the case, the jurisdictional boundaries of the Court would vary depending on the regulatory design adopted).

${ }^{26} / d$. at paras. $40-42$.

27 Id. at para. 43. The prerogatives of the Commission regarding technical standardization are detailed in Regulation (EU) 1025/2012, supra note 12, at art. 10.

${ }^{28}$ See CEN and CENELEC position on the consequences of the judgment of the European Court of Justice on James Elliott Construction Limited v. Irish Asphalt Limited (2017), https://www.cencenelec.eu/News/Policy_Opinions/PolicyOpinions/PositionPaper_Consequences_Judgment_Ellio $\mathrm{tt} \% 20$ case.pdf; See also Orgalime Position Paper, Call to preserve the EU 'New Approach' as one of the Single Market's best regulatory techniques (2017), http://www.orgalime.org/sites/default/files/positionpapers/Orgalime\%20Position\%20Paper\%20-\%20Save\%20the\%20New\%20Approach\%20-\%2007-03-2017.pdf (by The European Engineering Industries Association, a partner organization of CEN and CENELEC).

${ }^{29}$ See Carlo Colombo \& Mariolina Eliantonio, Harmonized Technical Standards as Part of EU Law: Juridification with a Number of Unresolved Legitimacy Concerns?, 24(2) MAASTRICHT J. OF EUR. \& COMP. L. 323 (2017); Annalisa Volpato, The Harmonized Standards before the ECJ: James Elliott Construction, 54(2) CoMmon MKT. L. REV. 591 (2017).
} 
aspects of the decision deal with the enhanced relationship between the judiciary and technical standardization.

The lack of judicial oversight has always been one of the most problematic features of European standardization, which also casts a shadow on the legitimacy of the rule-making powers exercised by the ESOs. ${ }^{30}$ Once the HSs enter EU law-and are accordingly embedded within the jurisdictional boundaries of the Court-a new intersection between the European Standardization System and the judiciary emerges, which potentially paves the way for a deeper role of the Court in standard-setting mechanisms. Because of that, James Elliott represents a turning point for the New Approach's paradigm; and yet, that was hardly unexpected.

Indeed, the judgment can be seen as a consistent development of an already existing trend aiming at proceduralizing European standard-setting activities, as primarily apparent in Regulation (EU) 1025/2012. It is the same Regulation that first suggests some kind of judicialization of European standardization. Confirming what was already established by the 2008 New Legislative Framework, ${ }^{31}$ the Regulation (EU) 1025/2012 seems indeed to imply that an action for annulment under Article 263 TFEU may be brought against the decision of the Commission publishing the HSs. Highly contested in the past, ${ }^{32}$ this circumstance can be

\footnotetext{
${ }^{30}$ The legitimacy of private standardization within the EU legal order has been sometimes contested in light of the Meroni non-delegation doctrine. See Josef Falke, Achievements and Unresolved Problems of European Standardization: The Ingenuity of Practice and the Queries of Lawyers, in INTEGRATING SCIENTIFIC EXPERTISE INTO Regulatory Decisionmaking - National TRaditions and European INNOVATIONS 187 (Christian Joerges, Karl-Heinz Ladeur \& Ellen Vos eds., Nomos 1997); Herwig C.H. Hofmann, Gerard C. Rowe, \& AleXander H. Türk, Administrative LAW AND POLICY OF THE EUROPEAN UNION, 247-49 (2011). Nevertheless, the delegation-focused debate on standardization seems to consider one side of the story only, as it assumes that private standard-setting bodies occupy a regulatory space that was previously controlled by public institutions only. On the contrary, it might also be the case that
}

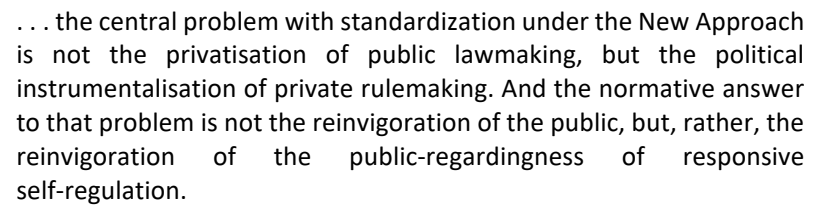

harm Schepel, The Constitution of Private Governance: Product Standards in the Regulation of Integrating Markets 257 (Hart, 2005).

${ }^{31}$ See Decision 768/2008, supra note 13 , at art. R9.

32 See Harm Schepel, The New Approach to the New Approach: The Juridification of Harmonized Standards in EU Law, 20 (4) MAASTRICHT J. OF EUR. AND COMP. L. 521, 528 (2013). See Report from the Commission to the Council and the European Parliament on "Efficiency and Accountability in European Standardization under the New Approach", at para. 6, COM (1998) 291 final, ("no positive decision is required by which authorities approve the standards, even if previously such technical aspects were subject of regulation"). As a consequence of the marginal involvement of 
now inferred by the wording of Articles 10(6) and 11 of the Regulation. The former obliges the Commission to proceed to publication only "[w]here a harmonized standard satisfies the requirements which it aims to cover and which are set out in the corresponding Union harmonization legislation." The latter regulates the so-called "formal objection procedure" that MSs and the European Parliament may trigger for raising a complaint about HSs, establishing that the Commission shall "decide" on the compatibility of standards with the standardization request and the essential legislative requirements. ${ }^{33}$ Evidently, both provisions suggest that the Commission plays an active role in the approval-of the contents-of HSs: in practice, it takes responsibility of the standards it publishes. Arguably, this makes the publication of HSs into the OJ a discretionary measure against which an action under Article 263 TFEU might be taken. ${ }^{34}$ Recently, the Global Garden case has confirmed that, plainly stating that "... the decisions relating to the publication of harmonized standards are legal acts against which an action for annulment may be brought." ${ }^{35}$

In this light, James Elliott might be interpreted as a complementary development of thealready existent-judicialization of the New Approach evoked by Regulation (EU) 1025/2012: While the latter paves the way to a judicial review of the publication of HSs under Article 263 TFEU, the James Elliott judgement deals with the "other leg" of the Court's jurisdiction, opening the doors to a judicial oversight of HSs per se under Article 267 TFEU. ${ }^{36}$

The abstract possibility to bring the HSs before the Court through Article 267 TFEU, however, little says about its actual likelihood. There are, indeed, some elements that might downsize the potentialities of this new strand of judicial proceedings.

Usually, standards establish detailed technical specifications for given categories of products, drafted in highly specialized language, and often complemented by mathematically-expressed requirements. Therefore, HSs tend to be-to a certain extentunequivocal. On the contrary, hermeneutic-legal-activities presuppose lacunae and/or semantic ambiguities: Only when grey areas exist-in claris non fit interpretatiointerpretation makes sense. Under this premise, technical standards do not seem to

public authorities in technical standardisation, there were no legal acts of the EU institutions that might be brought before the Court.

\footnotetext{
${ }^{33}$ Regulation 1025/2012, supra note 12, at art. 11(1).

${ }^{34}$ Schepel, supra note 32 , at $530-31$.

${ }^{35}$ Case T-474/15, Global Garden Products Italy SpA v. Commission, 2017 E.C.R. 36, para. 60.

${ }^{36}$ An opening of the Court in this direction could have already been inferred-a contrario-in Case C-185/08 Latchways plc \& Eurosafe Solutions BV v. Kedge Safety Systems BV \& Consolidated Nederland BV, 2010 E.C.R. I9983, para. 32. Here, the Court neglected its jurisdiction over a technical standard not requested by the Commission because they had no links whatsoever with EU law. This suggests that different circumstances-i.e. where a request from the Commission exists-might have led the Court to affirm its jurisdiction.
} 
represent a prolific ground for judicial interpretation. The James Elliott decision makes no exception: The interpretative issues it raises do not directly concern the technicalities of the construction standard at stake, but rather its "function" and legal significance in connection with both the presumption of conformity established by EU harmonization legislation and national law.

From a different point of view, it remains unclear whether or not the Court's opening toward HSs shall embrace both interpretative and validity questions under Article 267 TFEU. Some elements might suggest a negative answer. First, there is nothing in the reasoning of the Court that points in this direction: The James Elliott decision never mentions a possible extension beyond interpretative matters, nor it does the case-law the Court refers to. The limited scope of the preliminary reference mechanism could, however, have determined the silence of the Court in that regard. Second, though implementing EU law, it is debatable whether national standards transposing HSs can be brought before a domestic tribunal, and possibly ground a preliminary reference to the Court. The chance of a judicial review of technical standards at the national level is indeed largely determined by the institutional and legal landscape of each MS. In some MSs and EFTA countries, NSBs are connected to public authorities by institutional or para-institutional links and can therefore be considered public bodies. In many others, the state-standardisation body relationship is merely contractual. ${ }^{37}$ Most of the times, technical standards have a prevalently private legal status and are accordingly considered to be a self-regulatory tool. Therefore, it comes as no surprise that in most MSs the chance of judicial scrutiny over technical standards is still a contested prospect; simply, standardization outcomes are perceived to fall beyond the scope of judicial review. ${ }^{38}$ On the other hand, it would be questionable to maintain that the Court can interpret HSs as measures which are "part if EU law", but cannot assess their validity. It would be controversial, for instance, to argue that where the rules established by Regulation (EU) 1025/2012 are breached, the validity of the resulting standard is not a matter for the Court to rule upon. The Regulation establishes a set of procedures that the ESOs and the Commission are bound to follow during standard-setting, ${ }^{39}$ including rules supporting the participation of social stakeholders. ${ }^{40}$ Failing to comply with these rules amounts to a procedural defect which surely affects the validity of the HS and, in turn, of the corresponding implementing national standard. A radical rejection of the chance to refer a preliminary ruling on the validity of HSs might therefore come to the detriment of the effectiveness of the Regulation.

37 Cf. Harm Schepel \& Josef falke, legal Aspects of Standardization in the Member States of the eC and efta: COMPARATIVE REPORT V. 168 (2000).

${ }^{38}$ See Rob van Gestel \& Hans-W. Micklitz, European Integration Through Standardization: How Judicial Review is Breaking Down the Club House of Private Standardization Bodies, 50 (1) CоммоN MкT. L. REv. 145 (2013).

${ }^{39}$ Regulation 1025/2012, supra note 12, at art. 10.

${ }^{40} / d$. at art. 5. 
On the background of the aforementioned issues, lie more general concerns: Would the Court be able to interpret technical standards? Is it cognitively equipped to do so? To what extent judicial activity should enter science-led decision-making ? $^{41}$ The unsuitability of European judiciary-and any non-specialized tribunal-to interpret highly technical documents could not go unnoticed in the wake of James Elliott. In this respect, the CEN and CENELEC indeed

\begin{abstract}
... propose to the Commission to set-up a structured process of "technical interpretation on ENs" [European standards] that will be made available to the Commission, whereby the ESOs provide technical interpretation of hENs [harmonized standards]through the expertise of their Technical Committees-in support to the EC where it is itself involved in a court case brought to the European Court of Justice involving hENs. This in view to ensure that the European Court is provided with the correct interpretation on the hENs, while allowing CEN and CENELEC to have visibility on the European Court cases involving their standards. ${ }^{42}$
\end{abstract}

In technology-led societies, tribunals might not be able to refrain from dealing with science: ${ }^{43}$ technical expertise shall be integrated into judicial proceedings one way or another. Nevertheless, this might open the door to a veiled delegation of adjudicatory power in favor of the experts appointed by the judges, as few times the latter would go against scientists' advice. This worry is not merely abstract ${ }^{44}$, arguably representing one of the factors that lie behind the reluctance of the Court to "[...] entrust any individual, body, authority, committee or other organization it chooses with the task of giving an expert opinion." ${ }^{45}$ For this reason, any influence and scientific support from the ESOs-even though mediated by the Commission-should be framed carefully. Even though it is certainly true

\footnotetext{
${ }^{41}$ See generally Ellen Vos, The European Court of Justice in the Face of Scientific Uncertainty and Complexity, in Judicial Activism AT the European Court Of Justice 142 (Mark Dawson, Bruno de Witte, \& Elise Muir eds., Elgar, 2013).

${ }^{42}$ CEN and CENELEC position paper, supra note 28 , at para. 7.

${ }^{43}$ Case C-269/90, Hauptzollamt München-Mitte v. Technische Universität München, 1991 E.C.R. I-5469 (Opinion of Advocate General Jacobs at para. 13. Nowadays judges "cannot shy away from technical questions.").

${ }^{44}$ See Eric Barbier de la Serre \& Anne-Lise Sibony, Expert evidence before the EC Courts, 45(4) COMMON MKT. L. REV. 941, 961 (2008).

45 Statute of the Court of Justice of the European Union art. 25.
} 
that CEN and CENELEC did develop the HSs in the first place and can count on a broad technical expertise, their involvement in judicial proceedings cannot because of that alone aspire to provide the "correct interpretation" of HSs. HSs are EU implementing law, and as such their interpretation remains primarily a matter for the Court of Justice to decide.

\section{E. The Private Side of James Elliott: The Interplay Between Harmonized Technical Standards and National Legal Standards}

The debate about James Elliott has been largely monopolized by its public law implications. No attention has - on the contrary-been given to the other side of the judgment, which deals with the relationship between HSs and national contract law. Yet, this aspect is worth specific consideration, as it builds upon the still under-investigated role of technical standards in private law relationships.

\section{The Autonomy of Harmonized Standards and National Private Law}

Having established its jurisdiction under Article 267 TFEU, the Court examines the role played by the HS at issue in the context of the contractual relationship between James Elliott Ltd. and Irish Asphalt Ltd. The findings of the Court can be split into two main blocks.

(i) The interplay between technical standards and national contract law is touched upon by the Court in referred questions 1 (b) and 3, which suggest a joint analysis. The former investigates whether non-compliance with the HS EN 1342:2002 shall be established by courts only with reference to the means of proof therein indicated and at the time of the supply of the product. The latter inquires whether domestic courts are bound to consider the presumption of conformity attached to HSs when asked to assess the fulfilment of "merchantability" or "fit for purpose" clauses established under national contract law. In other words, the referring court asks, on the one hand, whether compliance with HSs could be established by whatever method and at any time, while on the other hand, whether conformity with such standards obliges the judge to presume that the "implied condition that the goods supplied under the contract are of merchantable quality" has been fulfilled. ${ }^{46}$ In both instances, the Court grounds its reasoning on the same argument: The exclusive scope of Directive 89/106/EEC and the corresponding HSs is to eliminate technical barriers to intra-Union trade. ${ }^{47}$ Under no circumstances can the Directive-and New Approach legislation in general-harmonize national private law, including the rules applicable to proof in contractual disputes and contract law clauses established by law. In principle, there is no convergence between national private law and European technical harmonization; rather, they move along parallel and autonomous lines.

\footnotetext{
46 Sale of Goods Act $1893 \quad$ (Pub. Stat. No. 71/1893) (Ir.), http://www.irishstatutebook.ie/eli/1893/act/71/enacted/en/print.

${ }^{47}$ Case C-613/14, supra note 1, at para. 51 (Opinion of Advocate General Campos Sánchez-Bordona).
} 
In light of this, there was no need for the Court to address referred questions number four and five, which were subordinated to the affirmative answer to the third question.

(ii) From a different point of view, the Court clarified whether legal clauses such as "merchantability" and "fitness for purpose" clauses can be considered "technical regulations" within the meaning of Directive 98/34/EC. In case of an affirmative answer, Article 14(2) of the Irish Sale of Goods Acts introducing a merchantability clause should be disapplied, as it was not notified to the Commission in accordance with the established procedure. The Court went through all the possible meanings of "technical regulation," 48 eventually concluding that a merchantability clause does not fall within any of them.

\section{Bridging Technical Standards and Legal Standards in the Practice of Law}

From a private law perspective, the most intriguing points of the judgment emerge from the Court's understanding of the interplay between technical harmonization and national contract law, as depicted by paragraph (i) above. Specifically, the Court addresses the relationships between a technical standard referred in a private contract and a legal standard established by domestic law. How do technical and legal standards coordinate? Do they overlap? And if so, to what extent?

The argument used by the Court is eminently teleological: New Approach legislation and the connected HSs have the sole goal to eliminate technical barriers to trade within the Internal Market. $^{49}$ No harmonization of national private laws is intended. As a consequence, technical standards shall not affect the discretion of domestic courts when it comes to applying national contract rules: HSs and legal standards do not overlap, nor do the former necessarily contribute to the judicial shaping of the latter. In the understanding of the Court, technical standards and national contract law belong to different layers of regulationmarket and contract-which pursue autonomous goals and ground different and independent judicial appraisals.

${ }^{48} / d$. at para. 65. According to Art. 1(11), Directive 98/34/EC "technical regulation" refers to

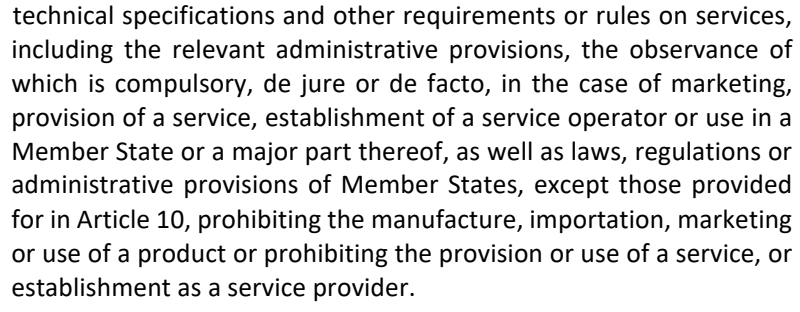
including the relevant administrative provisions, the observance of which is compulsory, de jure or de facto, in the case of marketing, provision of a service, establishment of a service operator or use in a Member State or a major part thereof, as well as laws, regulations or administrative provisions of Member States, except those provided for in Article 10, prohibiting the manufacture, importation, marketing or use of a product or prohibiting the provision or use of a service, or establishment as a service provider.

${ }^{49}$ Case C-613/14, supra note 1, at para. 51 (Opinion of Advocate General Campos Sánchez-Bordona). 
Nevertheless, this approach risks being excessively formalistic. A watertight separation between technical-not necessarily harmonized-standards and private law could indeed underestimate the influence of the former on the factual application of the latter. In spite of their intended goal, in fact, technical standards might enter private law through a practical process, not always legally endorsed, ${ }^{50}$ which depends on market pressures and/or the penetration of standards into the practice of business contracts, and from there enters into judicial adjudication. Private agreements may refer to widespread technical standards for specifying the characteristics of the performance(s) agreed, as it occurred in James Elliott. Similarly, judges-and the experts they appoint-can refer to technical standards when it comes to disentangling highly technical issues or filling with content abstract legal provisions - such as standards of care and "quality standards," including "merchantability" clauses. As Schepel efficaciously put it, "... armed with such vague generic legal requirements in the face of a vastly complex world, it is only logical that courts look to standards." ${ }^{\prime 11}$ By these means, largely accepted technical standards inevitably acquire evidential significance in private law disputes. ${ }^{52}$

Seen against this backdrop, the argument that technical standards and legal standards follow independent and parallel paths might not reflect the reality. Rather, it would be reasonable to believe that the former play a role in the concretization of the latter. This is likely to happen especially whenever technical standards are so deeply embedded in the established practices of an industry that they stand as points of reference for manufacturers. In this case, it is certainly probable that goods not compliant with the generally-accepted technical standards of the industry would also-because of that alone-fail to meet the expected characteristics or the merchantable quality. Any different solution, which would acknowledge that goods are of the expected quality despite the non-conformity with a widely-used technical standard, could be sometimes perceived as paradoxical and incoherent with the business practice in place.

\footnotetext{
${ }^{50}$ At least not always, and never directly. HSs do have some sort of institutional support, as they provide compliant goods with a presumption of conformity with legislative requirement that binds Members States' authorities. Surely enough, this presumption is attractive to manufacturers, and therefore contributes to the diffusion of HSs within European markets. Only in this sense HSs can be deemed to have a legally-meaningful endorsement from EU institutions.

${ }^{51}$ SCHEPEL, supra note 30 , at 342.

${ }^{52}$ SCHEPEL \& FALKE, supra note 37 , at 231
}

... as a sociological matter, the more standards are used and accepted not only in the professional circles concerned but by the public at large, the more they can be considered to form part of the normative structure of society and hence to be capable of laying down baseline requirements of appropriate behaviour.

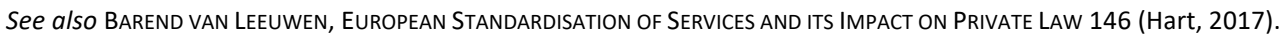


In some circumstances-which should ideally be appreciated with an empirical approach ${ }^{53}$ the boundary between legal standards and technical standards might therefore blur. Against this backdrop, the stance of the Court in James Elliott should not be taken in absolute terms: Although not purposely, HSs might exert a subtle harmonizing effect over the actual unfolding of private law, inevitably influencing the judicial concretization of legal standards established by different national laws. As standardization expands toward the market of services, it is likely that this influence will deepen and strengthen in the near future. ${ }^{54}$

Nevertheless, the intersection between technical standards and national private laws in practice should not hide, nor belittle the concerns which glimpse through the reasoning of the Court. The formal separation between technical and legal standards is indeed necessary to maintain the autonomy of tribunals interpreting and applying national law. Moreover, it preserves the discretion of national judges against the influence of technical bodies.

As regards the former aspect, the stance of the Court safeguards the division of competences between the Union and the MSs, which would be undermined if HSs could lay down not only uniform conditions for market access, but also the contents of abstract clauses established by national contract law. ${ }^{55}$

As regards the latter, the separation endorsed by the Court avoids a surreptitious shift of adjudicatory powers from the judiciary to standardization bodies-or to the market contingencies which determine the dominant role of a technical standard within a given business sector. As argued above, technical standards might de facto establish a benchmark against which market players shape their contractual relationships. As standards are embedded-explicitly or not-into business agreements, judges and legal professionals might be prone to align the legal standards they are entrusted to apply with the technical rules referred to-or reasonably taken into account-by the parties.

\footnotetext{
${ }^{53} \mathrm{~A}$ clear understanding of the penetration of standards in private law would require a comparative and sectorial empirical analysis, which considers the relevance of technical standards in a specific industry. Some interesting empirical insights are offered, at least as regards tort law, in LEEUWEN, supra note 52, at 167-68.

${ }^{54}$ Standardization of services has formally entered the EU agenda with Regulation (EU) 1025/2012, supra note 12. This results in new challenges for standard-setting activities and raises some concerns about the impact of service standards on private law. See generally Panagiotis Delimatsis, Standard-Setting in Services: New Frontiers in RuleMaking and the Role of the EU, in RESEARCH HANDBOOK ON TRADE IN SERVICES 268 (Pierre Sauvé and Martin Roy eds., Elgar, 2016).

55 The European Union does not have general competence over private law matters. It has, however, sectorial regulatory powers - for example in consumer protection-and broader regulatory tools-for example legislation under TFEU arts. 114-15-for steering private law across the Member States. See Stephen Weatherill, Competence and European Private Law, in THE CAMBRIDGE COMPANION TO EUROPEAN UNION PRIVATE LAW 58 (Christian Twigg-Flesner ed., CUP 2010).
} 
Nevertheless, this convergence may have problematic side effects. The un-critical overreliance on technical standards by judges risks creating a worrying interference between technical and legal rules, which might eventually lead to their overlap. That would indirectly put in jeopardy the space of legal discourse: If conformity with technical standards were to be considered a sufficient element for fulfilling abstract legal standards under contract law, judicial autonomy would be excessively eroded. The overlap between technical and legal standard would this way result in a veiled-though substantial-shift of powers in favor of the-often private-bodies developing technical specifications for application in the manufacturing and marketing of goods and services.

In conclusion, while the points of contact between technical standards and legal standards should not be neglected-as the ones inevitably influence the concretization of the othersit is at the same time essential to stress their autonomy and separate roles. In the case of HSs, the separation is primarily functional to preserve the allocation of competences between national and EU legal orders. More generally, keeping a clear-cut boundary between technical standards and legal standards is also necessary for safeguarding the role of judicial authorities in the application of private law.

\section{F. Concluding Remarks}

It is still not clear the impact on the European standardization system that the James Elliott decision will have in the long run. This Article briefly looked at the main findings of the judgment, stressing both public law and private law aspects.

First, it has been underlined that the Court embeds HSs within EU law building upon three main arguments. First, as HSs implement EU harmonization legislation, they shall reasonably fall within the scope of the preliminary ruling mechanism in order to ensure the uniform application of EU law across the MSs. Second, the publication of the HSs in the OJEU grounds a presumption of conformity with legislation which MSs are legally bound to respect. That implies some kind of institutional endorsement of HSs, which justifies their inclusion within EU law. Third, the pervasive role played by the Commission in the New Approach standardization amounts to a substantial control over HSs, that further argues in favor of their belonging to the EU acquis.

The widening of the Court's jurisdiction toward HSs has been examined in connection with Regulation (EU) 1025/2012, to which it represents a consistent addition. While the Regulation acknowledges some space for judicial intervention in New Approach standardization through an action for annulment against the publication of HSs, the James Elliott ruling paves the way for a judicial oversight over HSs under Article 267 TFEU. Nevertheless, the width and feasibility of this new strand of standardization-related proceedings is still to be assessed. Indeed, on the one hand, technical specifications do not seem to be a prolific ground for judicial interpretation, as they do not leave much space to ambiguities. On the other hand, it is still to be clarified whether the reasoning of the Court 
would also open to validity questions on HSs under Article 267 TFEU. Although appropriate for ensuring the effectiveness of the Regulation (EU) 1025/2012, it is stressed that it could be difficult for national standards implementing HSs to be taken before a domestic tribunal because of their private legal nature. In turn, that might radically downsize the chance of a preliminary reference on the validity of HSs.

In addition, there are serious doubts about the ability of the Court to deal with the highly technical questions that may be implied in the review of HSs. In this regard, CEN and CENELEC - two of the three European Standardization Organizations-have proposed to establish an "interpretation mechanism" by which they advise the Court. This-and any other-technical support to the judiciary should however be framed in a way that does not jeopardize the interpretative discretion of the Court.

Second, the private law aspects of the James Elliott judgment have been stressed. The Court concluded that national judges are not bound to refer to HSs when defining the contents of-and assessing compliance with-contractual clauses established under national law, such as a merchantability clause. As HSs are exclusively intended to facilitate the free movement of goods within the Internal Market, they cannot harmonize national contract law and thereby limit the discretion of domestic judges. Nonetheless, a rigid separation of the judicial appraisals of technical standards and legal standards appears artificial. Especially when technical standards are deeply embedded into business practices, both the parties of a contract and judges take them into account for filling with contents abstract legal standards - such as the merchantable quality of goods. In practice, technical standards and legal standards might intersect, therefore fostering convergence among national contract laws. At the same time, it should be noted that the separation of HSs and national legal standards depicted by the Court is necessary for preserving the division of competences between the Union and MSs, as well as for avoiding a worrying overlap of technical standards and legal standards-which might eventually lead to a surreptitious shift of adjudicatory powers in favor of the standard-setting bodies. 
